\title{
Local economic development policies in Chile's municipalities: beyond welfarism
}

\author{
Felipe Correa and Marco Dini
}

\begin{abstract}
To what extent are local economic development policies limited to a welfare approach in Chile? The hypothesis pursued in this work is that, taken together, these policies far exceed this paradigm. For the study, a register of 40 policy categories was taken by means of a reading and systematization of local economic development policies run by Chile's municipalities through 69 District Development Plans (PLADECO). On average, municipalities propose actions in 16 of the 40 categories, but these, overall, are capable of encompassing in a satisfactory manner the various local economic development challenges faced by each municipality depending on the district's production structure and situation.
\end{abstract}

\section{Keywords}

Economic development, local development, development policy, development plans, employment, human resources, productivity, enterprise development, development indicators, municipal government, Chile

\section{JEL classification}

$\mathrm{H} 75, \mathrm{O} 18, \mathrm{R} 58$

\section{Authors}

Felipe Correa is Research Assistant in the Division of Production, Productivity and Management of the Economic Commission for Latin America and the Caribbean (ECLAC). Email: felipe.correa@un.org.

Marco Dini is Economic Affairs Officer in the Division of Production, Productivity and Management of the Economic Commission for Latin America and the Caribbean (ECLAC). Email: marco.dini@un.org. 


\section{Introduction}

The importance of the local economic development approach has been emphasized in a vast body of literature, which has also drawn attention to territorial dynamics in the generation and diffusion of knowledge, especially the adaptive and tacit knowledge that arises from the interaction between members of local production systems. The literature also underlines the contribution of social cohesion to stimulating the diffusion of good practices and shared learning in terms of strengthening resilience and capacity to adapt in response to external shocks and the generation of the social capital of mutual trust that underpins the external organization of labour models promoted by firms' production specialization (especially smaller firms) and the complementarity of independent firms (Alburquerque and Dini, 2008; Alburquerque, 2004 and 2013; Becattini, 2002; Bianchi and Labory, 2014; Camuffo and Grandinetti, 2005).

To this disciplinary aspect is added the political importance exemplified by the declarations of the United Nations Conference on Human Settlements (Habitat II, held in 1996) and the more recent United Nations Conference on Housing and Sustainable Urban Development (Habitat III, held in 2016). The outcome document of Habitat III attributes a key function to the concept of local economic development because it equates local intuitions with those operating at the national or regional level and expresses the commitment of the signatory governments to taking steps to strengthen local institutions to support local economic development (United Nations, 2016).

Local governments throughout the world are key actors in the design and implementation of economic and development policies. Their knowledge of local realities and, especially, of the needs, interests and potential that define and drive local stakeholders gives them important tools for designing relevant and effective programmes. At the same time, their proximity to members of the community gives them more opportunities to generate spaces for dialogue and effective participation that will help to activate the area's human and material resources and harness them for the design, implementation and ongoing review of economic development activities.

To understand how and to what extent local governments have put into practice those elements that make them drivers of the economic development process, it is essential to analyse the progress of the policies they have put forward. This analysis should become more frequent as more and better information becomes available.

However, although it is recognized that local governments make just as important a contribution to shaping development policies as national or regional institutions (United Nations, 2016), reflection and study of the matter has been notably lacking within economic thinking, at least with regard to Latin America, and certainly to Chile. It may be that the unitary nature of the State in Chile - unlike other Latin American States, where federal organization affords greater importance to the local aspect of development policy - has led to municipalities being historically treated as "the poor relation" of the State (Salazar, 2013).

This study contributes to the necessary reflection - almost absent today - on local economic development policies in Chile. Although there has been a certain amount of literature involving qualitative study and synthesis of local development policies and experiences in Latin America (Alburquerque, 2004), this has not been true of Chile and there is an acknowledged lack of study on the topic (Bravo, 2012).

By reviewing the District Development Plans (PLADECO) of 69 of the country's largest comunas, or administrative districts, we identified 40 categories of local economic development policy action, involving a broad range of aspects related to the matter. This analysis is thus intended as a first attempt at a systematic study this of type of policy in Chile. 
The local economic development policies analysed also revealed innovative experiences in specific districts, beyond the traditional approach of production development policies typically applied by local governments. Traditional policies, confined to training, labour intermediation and the provision of information on central government development schemes, fall within what several authors consider to be a primarily welfarist approach (Alayón, 1991; Ziccardi, 2004; Artigas, 2005; Illanes, 2010), referring to a policy philosophy that treats agents of production more as passive recipients of programmatic assistance than as active subjects. The question behind this study is the extent to which local economic development policies are limited to this welfarist approach. In this regard, isolated knowledge of Chile's diverse local economic development initiatives led us to raise the hypothesis that the country's municipalities, seen as a group, far exceed the welfarist framework in terms of local economic development policies.

The research findings suggest that a significant number of municipalities in Chile exceed the traditional framework of actions governed by the welfare perspective. Each municipality has done so in its own manner, obliged perhaps by the pressure that comes with understanding economic development as a responsibility of the local government as much as of the central government.

However, economic development policies that go beyond the traditional framework do not entirely abandon the welfare approach - which represents the starting point - but, by broadening their range of responsibility, they integrate the welfare-type action into a more linked-up development strategy. Economic development plans with public participation, production activities directly based within local government agencies and institutional schemes of public-private coordination are examples of this transformation.

The rest of this article is organized as follows. Section II contains a description of the information sources used and the method applied. Section III describes the local economic development policies that it was possible to capture, ordered by 40 proposed categories. It includes a description of each policy and some elements that could contribute to models for policymaking. Section IV offers reflections on the characteristics of the most and least active districts, with a view to arriving at an initial identification of factors that determine the most dynamic policies. The last section concludes with a summary of the main findings and proposes future lines of research.

\section{Method and data sources}

Under the framework law on municipalities (Ley Orgánica Constitucional de Municipalidades), municipalities are exclusively responsible for preparing, adopting and amending their District Development Plan (article 3) and essential part of this is executing the Plan and the programmes necessary for its accomplishment (article 5). The District Development Plan is thus one of the four basic instruments of municipal administration (article 6). ${ }^{1}$ Under the law, the District Development Plan, the guiding instrument of local development in the district, contains actions aimed at meeting the needs of the local community and promoting its social, economic and cultural advancement (article 7). In other words, the Plan is acknowledged as perhaps the most important element of local policy.

Among the studies that have used information from District Development Plans are those by Montecinos (2006), Arredondo, Toro and Olea (2007), Valenzuela (2007), Olea (2011), Ruz and others (2014) and Orellana, Mena and Montes (2016). However, as in most of the cases mentioned, these studies have focused on the analysis of processes. That is, they evaluate formal characteristics of the process of preparation of District Development Plans, such as public participation, transparency and accountability and, in general, formal institutional and governance-related aspects. Although it captures essential elements of the local planning process, this approach does not necessarily capture the contents of these plans, which could possibly be beneficial for comparative study of policies.

1 The other three are the District Land Use Plan, the annual municipal budget and the human resources policy. 
As part of this work, each District Development Plan was fully read individually to prepare statistics on the frequency of each policy category. Software was not used, as it was considered that the complexity of the classification required, at least at the initial stage, a non-mechanical interpretation of the texts.

In 2017, Chile was divided into 15 regions, divided in turn into 54 provinces, made up of 346 districts (comunas) and 345 municipalities. ${ }^{2}$ At the district level, according to the 2012 census, 52 districts had over 100,000 inhabitants, and a further 107 had between 20,000 and 100,000 inhabitants. The choice of districts for the study of District Development Plans was based on the criterion of the Chilean Unemployment Fund Management Company (AFC Chile), ${ }^{3}$ which began operating in 2013 with branches located in districts that met one of the following conditions: (i) a regional capital; (ii) a provincial capital, or (iii) over 100,000 inhabitants. Provincial capitals with less than 20,000 inhabitants were also disregarded. ${ }^{4}$ This study thus reflects principally the particularities and needs of the large and mainly urban districts.

Of the 69 District Development Plans analysed, $55-80 \%$ of them- were in operation at the time of the study and most of the municipalities where this was not the case were engaged in updating them. The framework law on municipalities (article 7) establishes that a District Development Plan must encompass at least four years, but sets no maximum duration. The information in the sample of 69 plans yielded an average duration of 4.6 years, with considerable dispersion and a positive correlation between the size of the district and the planning timeframe: the more populous districts have a longer planning horizon, while the smaller districts come close to the four-year statutory threshold (see figure 1). ${ }^{5}$

Figure 1

Chile: planning horizon of District Development Plans in relation to district population (Number of years and of inhabitants)

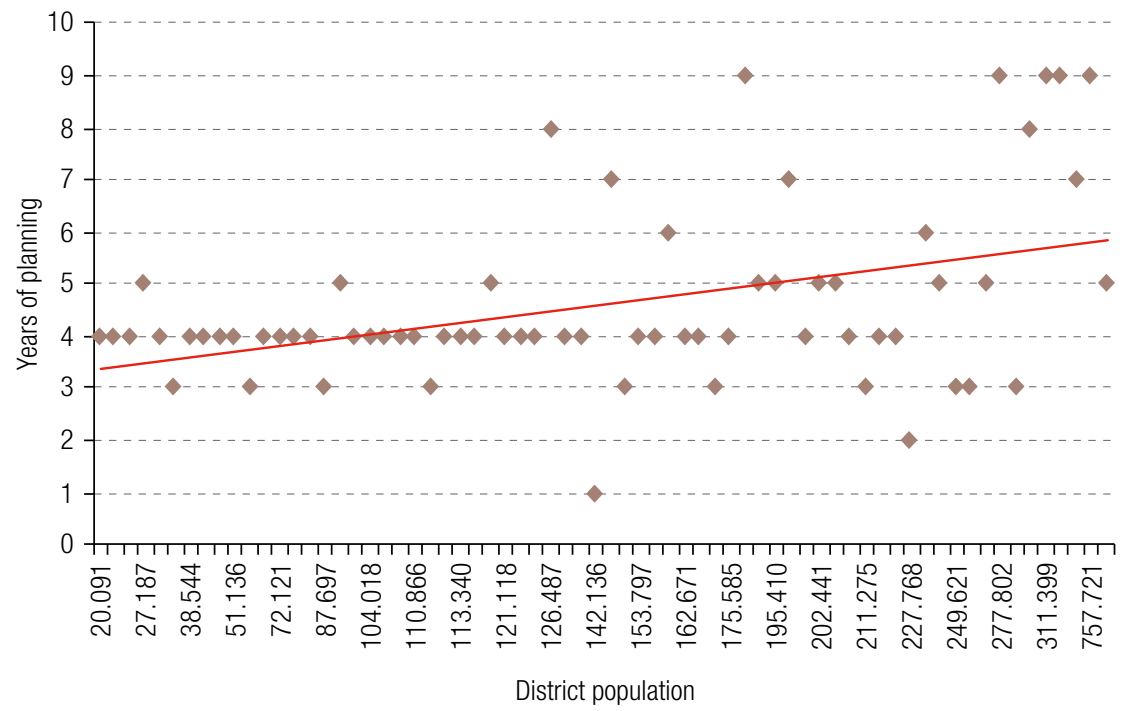

Source: Prepared by the authors, on the basis of District Development Plans.

2 The Municipality of Cape Horn administers the districts of Cape Horn and Antarctica.

3 AFC Chile administers unemployment funds and thus has a direct link with some municipalities through local development and labour intermediation agencies (such as Municipal Labour Intermediation Offices, OMIL), which certify unemployment in the case of insurance claims through the solidarity-based unemployment fund. This ensures that municipalities have at least a threshold level of institutionality and policy geared towards employment, labour intermediation, training and development.

4 Previous studies analysing District Development Plans and including a larger number of districts are those by Ruz and others (2014), which covers 30 districts, and Orellana, Mena and Montes (2016), which covers 58.

5 The following districts have a planning horizon of nine years: Puente Alto, Antofagasta, Viña del Mar, San Bernardo and Curicó. 
Another matter to consider is the process of preparation of District Development Plans. According to data from the Public Procurement Department (ChileCompra), between 2009 and 2015 a total of 214 tenders were awarded in relation to updating these plans (see figure 2). In 2015 alone, there were 48 tenders, which shows that many municipalities are outsourcing this function. Crossing the information contained in the sample used and that from ChileCompra shows that at least $58 \%$ of the plans consulted were prepared by external consultancy firms.

Figure 2

Chile: tenders related to the preparation and updating of District Development Plans, 2009-2015

(Number of tenders)

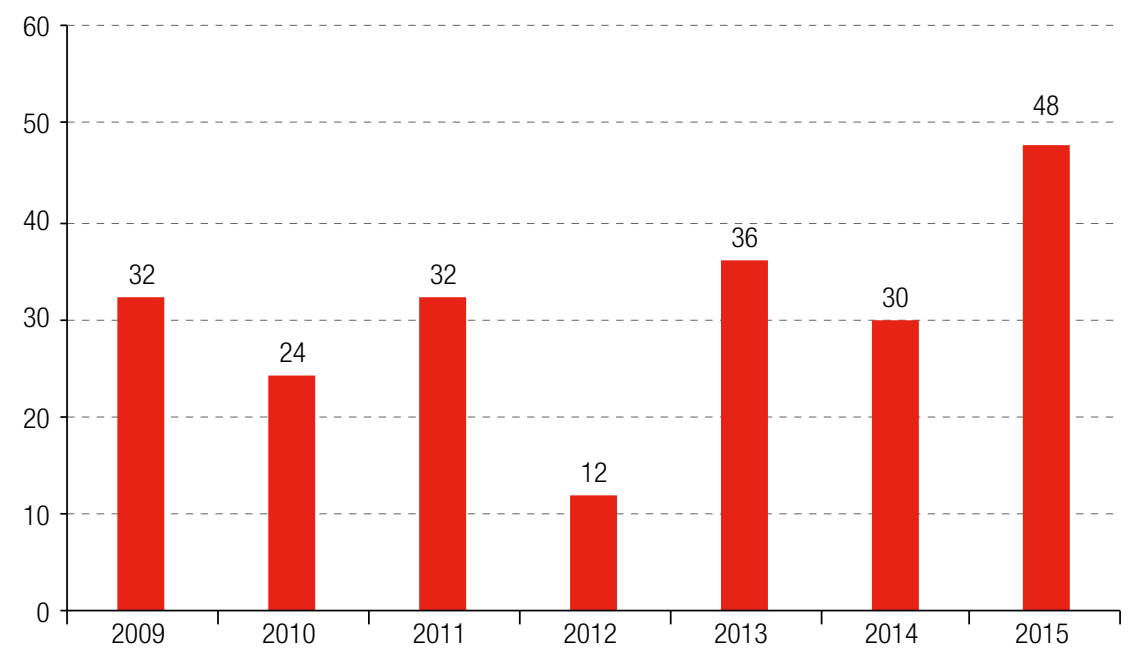

Source: Prepared by the authors, on the basis of information from the Public Procurement Department of the Ministry of Finance.

The shortage of staff with the skills needed to perform this task likely accounts in part for this situation. However, the decision to delegate this function to an entity external to the municipality may seriously limit the effectiveness of the proposal and weaken the creation of autonomous capacities within the municipality. When it is carried out in direct contact with local stakeholders, the process of interpreting the economic and social reality is not merely an exercise in information-gathering, but also a key instance for building trust between the municipality and the members of the respective community, which is vital if the proposals that arise from the process are to enjoy the support and legitimacy needed for implementation, on the part of both the local government and the citizens.

\section{Register of local economic development policies}

The sections of District Development Plans that address economic and productive development sometimes include plans, programmes or activities that are not directly linked to the subject. At the same time, some measures that have to do with economic and productive development are spread across different sections of the Plans, such as education, rural development, indigenous issues, the environment and urban development. These measures are not included in the study, since the idea is to present only what is considered part of economic and productive development in each Plan: a self-definition of economic development policy, as it were. However, as will be seen below, economic and productive development intersects with many other aspects that are not themselves strictly economic. This must be borne in mind to obtain a systematic vision of the development process and for the coordination between different public and private agents working in the territory. 
Furthermore, where a plan, programme or activity relates to two or more categories, they are all included for the purposes of statistical preparation. Figure 3 shows the 40 categories into which local economic development plans were classified and the frequency with which they appeared in District Development Plans.

Figure 3

Chile: local economic development policies in municipalities' district development plans, 2016 (Percentages of municipalities analysed)

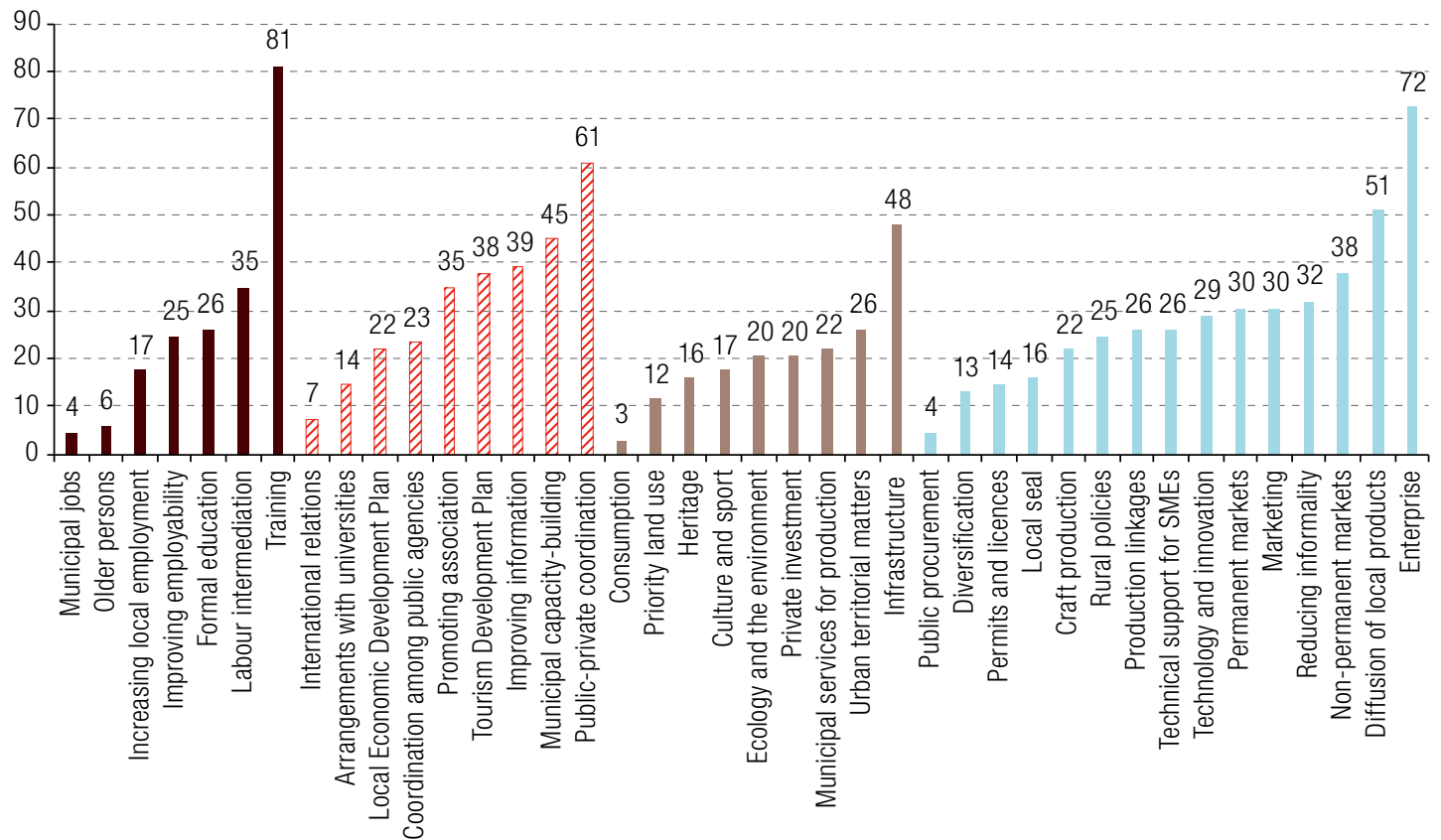

Employment and human capital ש Institutionality District production system Enterprise and business support

Source: Prepared by the authors, on the basis of District Development Plans.

In the first place, it may be seen that three policies are the most common in the municipalities: those on training, enterprise and public-private coordination. Conversely, the least frequent, although not necessarily the least important (for example, in terms of resource investment), are policies on consumption, municipal jobs, public procurement, older persons and international relations or agreements. At the same time, generally speaking, there are four major policy dimensions: (i) employment and human capital; (ii) institutionality; (iii) development of the local production system; and (iv) enterprise and business support. For the purposes of organization, the 40 categories are briefly reviewed below, framed within the four main lines of action.

\section{Employment and human capital}

Training-related policies are those that arise most often. They may refer to the teaching of skills to improve labour force employability, support for small enterprise (through training on mechanisms for starting a business, applying for funds or managing a business), training for municipal staff or training of community leaders on production development issues. As shown in figure 3, $81 \%$ of municipalities propose to carry out training activities. Prominent in this sphere are investments in building purpose-built physical spaces; ${ }^{6}$ planning of the supply of training according to the needs of the local production structure,

6 The most common actions include the establishment of local training or trade schools. 
for which many municipalities carry out studies of the district production system; and the creation and implementation of training agencies, Technical Training Agencies (OTEC). ${ }^{7}$ On this last point, according to data from the National Training and Employment Service (SENCE), in 2016 there were 43 municipal OTEC, 15 of them in the Metropolitan Region (see figure 4). The importance of these certified agencies for municipalities is that they afford access to public and private resources to pursue training activities.

Figure 4

Chile: municipal technical training agencies by administrative region, 2016

(Number of units)

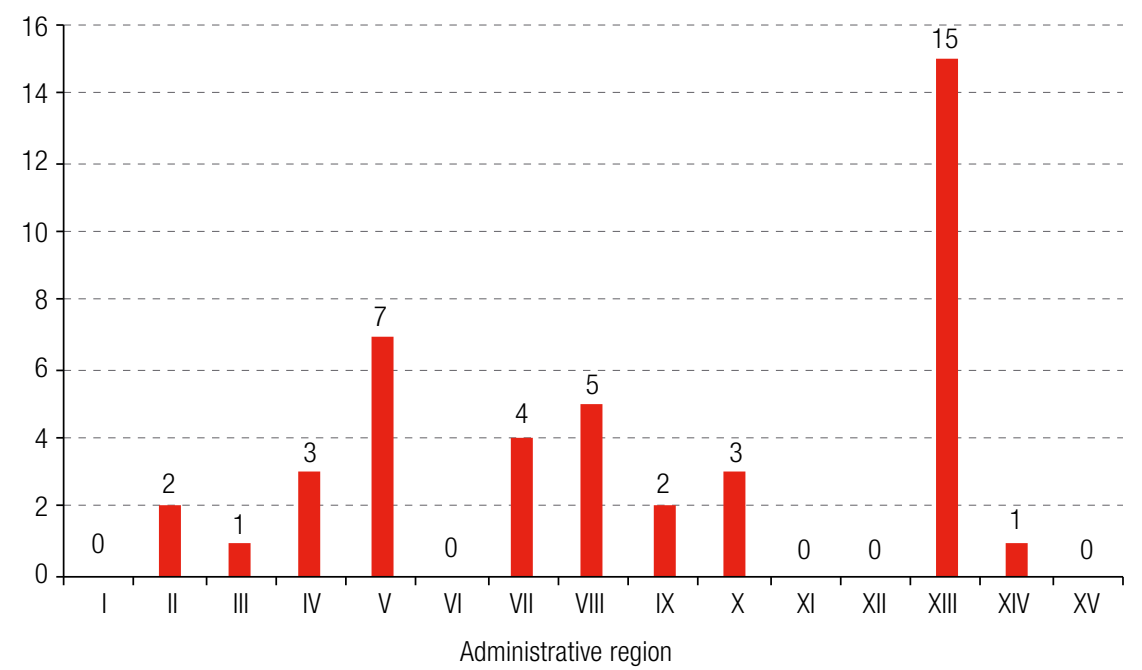

Source: Prepared by the authors, on the basis of data from the National Training and Employment Service.

Another policy area that concerns local human-capital-building is formal education, especially technical training. Municipalities today are responsible for the administration of technical secondary schools, and $26 \%$ of them envisage measures in this area in their District Development Plans. This enables them to plan the supply of technical education in keeping with the needs of the current and future production base and combine it with their vision of the local production system. This category also includes internships through arrangements with the private sector, training plans in the area of community work (as in the case of the district of El Bosque), active schooling recovery measures, preschool education and the establishment of municipal technical training centres (as in the district of Cerro Navia), among other areas.

Twenty-five per cent of municipalities have policies to increase workforce employability, through training, formal education and other types of activities, workshops on job-search preparation and certification in workforce occupations, competencies and quality (districts of Villa Alemana and Cerro Navia).

The concern with employment is also expressed in measures directed at reducing unemployment. Within that policy line, the most frequent are traditional labour intermediation tasks, which 35\% of municipalities propose to strengthen. Here the focus of attention is on improving the work of Municipal Labour Intermediation Offices (OMIL) through a variety of mechanisms, such as the OMIL capacity-building (FOMIL) programme under SENCE; the use of better information technologies within the municipality and the National Employment Exchange (BNE) to administer information relating to labour intermediation, and active linkaging of the municipality with the large private companies to capture more and better employment opportunities.

7 OTEC are institutions exclusively accredited by the National Training and Employment Service (SENCE) to perform training activities that may be eligible for tax concessions, and to be contracted by SENCE to impart publicly-funded courses. To obtain accreditation, a municipal OTEC must comply with Chilean standard 2.728 and ISO standard 9001:2008. 
Reducing unemployment is one of the local priorities of many municipalities, especially in so-called "dormitory" districts. Seventeen per cent of municipalities have proposed several lines of action in this respect, including incentives for private companies to hire local labour (this is the case of the plan in Maipú, for example) or bonus points for firms entering municipal tenders if they use local staff to perform the scheduled work (the district of Ovalle, for example). Similar unemployment-reducing measures have also been proposed for the work of the municipality itself. Four per cent of the plans examined contained measures of this sort, including preference for local labour in services provided by the municipality (Maipú), the use of public investment in the district as a mechanism for absorbing labour (Temuco) and an interesting idea associated with the concept of guaranteed work (Garzón and Guamán, 2015), whereby the municipality provides emergency jobs for those who need them as part of a continuous programme of urban upgrading in the district (Melipilla). Some municipalities gear employment-related programmes especially towards women and youth, which have specific lines of financing from the central government. In turn, $6 \%$ of municipalities include policies focusing on education, training, enterprise and employability of older persons.

\section{Institutionality}

The areas in the institutional sphere cover: the preparation of studies and the creation of information systems; the establishment of offices specializing in local economic development; the incorporation of technical staff in the municipality; local planning on the matter; public-private coordination and linkages among public institutions; and the promotion of partnerships in the private sector.

For proposals on training and formal education, as with policies on employability, it is again necessary to have more information about the production sphere in the district. In this connection, $39 \%$ of municipalities propose specific measures to improve the quality of their information. These include both the preparation of studies on the production sphere and the establishment of ongoing information systems. In relation to the latter, there are many proposals to draw up registers of firms and enterprises -including formal and informal activities and different sizes of firm - and of sources of employment. In the new scenarios, comprehensive, up-to-date information is crucial to be able to continually assess challenges.

Forty-five per cent of municipalities consider it necessary to strengthen local economic development. In this regard, and although it is not explicitly included in the framework law on municipalities as one of the units of municipal organization, many municipalities have begun to set up Local Economic Development Departments (DIDEL) with a view to stepping up action in this area and bringing together in one office those which were previously spread across several departments. A review of the websites of 158 Chilean municipalities of districts of over 20,000 inhabitants shows that $10 \%$ of them have a local economic development department (see figure 5), either formally established by municipal regulation or as a de facto arrangement. However, in most municipalities (74.7\%), the function of local economic development still resides in Community Development Departments (DIDECO), either as a unit or as a thematic office not devoted to local economic development exclusively. ${ }^{8}$

In some District Development Plans, municipal capacity-building also includes the incorporation of professionals specialized in advising entrepreneurs and firms that so require, and have full knowledge of the government plans and programmes to which firms and municipalities can apply for resources.

\footnotetext{
8 In this ranking, priority was afforded to research on the location of production development as a main or core activity of local economic development.
} 
Figure 5

Chile: departments where production development functions reside in municipalities, 2016 (Percentages)

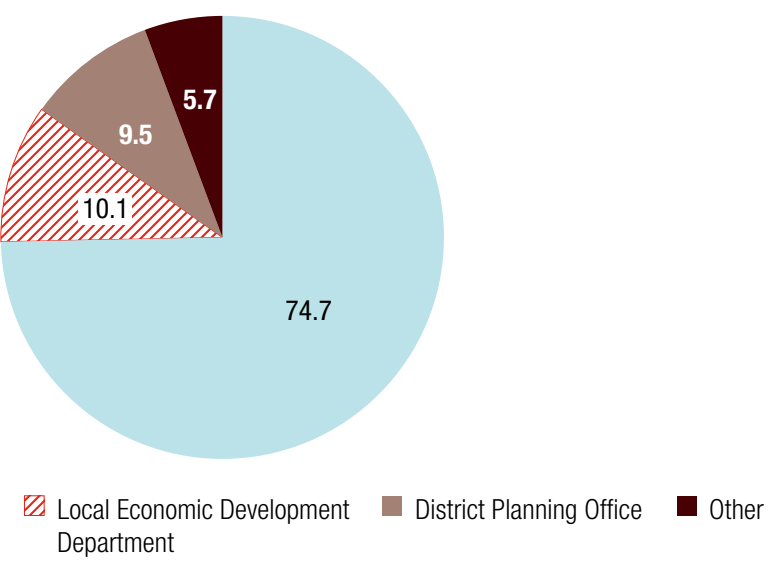

Community Development Department

$$
\text { Department }
$$

Source: Prepared by the authors, on the basis of municipalities' websites.

The category of municipal strengthening of economic and production development is closely tied in with the creation of a Local Economic Development Plan (PLADEL), ${ }^{9}$ a task in which $22 \%$ of the municipalities consulted report engaging. Another type of planning policy are Tourism Development Plans (PLADETUR), which are prepared by $38 \%$ of the municipalities studied. Interestingly, examining the municipalities that prepare Local Economic Development Plans and those that prepare Tourism Development Plans, only $9 \%$ propose developing both plans, while $29 \%$ make proposals on tourism without inserting them into a broader strategy of local economic development.

For preparing these plans - a task that should possibly be performed by Local Economic Development Departments - it is necessary to consider not only the points of view and fields of action of the municipality, but also those of other public bodies, civil society, trade union bodies and even other municipal departments. To this end, $61 \%$ of municipalities explicitly propose policies on strengthening public-private coordination. In addition, $23 \%$ make proposals on improving coordination with other State agencies and even with other municipal units whose spheres of action intersect with economic and industrial development activities, something that has been noted as crucial for the efficacy of local industrial development policies in Chile (Bravo, 2012). Most municipalities that propose public-private coordination refer to committees for different branches of activity.

Several District Development Plans also suggest establishing committees on the themes of the district production base under the auspices of the District Council of Civil Society Organizations. ${ }^{10}$ The challenge is to open up permanent instances of coordination that can offer a long-term perspective and contain the vision both of the municipality and of trade union bodies and civil society.

One of the problems identified in relation to public-private coordination is that industrial entities sometimes do not have union bodies. To address this issue, the municipality can foster association in its diverse forms, something that is included in 35\% of District Development Plans. This means fostering

9 Local Economic Development Plans are documents that 15 of the municipalities analysed propose to develop as complements to District Development Plans and which, from the point of view of the present study, reflect the intention of a fuller proposal on local economic development. They should not be confused with the economic or production development sections of the District Development Plans, which are the main sources of information in this analysis. The difference between the two plans is that the local economic development section of the District Development Plan refers to a medium- or long-term vision, while Local Economic Development Plans operationalize the proposals set forth in the District Development Plan by looking at the viability of concrete actions.

10 The District Council of Civil Society Organizations (COSOC) is a district body established under the framework law on municipalities (article 94) which operates as a counterweight to the mayor and the municipality in preparing and adopting municipal management tools (District Development Plan, the District Land Use Plan, the budget), among other matters of district interest. 
forms of association such as cooperatives, chambers of commerce, trade union bodies or simpler coordinating entities. For example, the district of Quinta Normal had a participation-related issue in that the idea of collective activity lacked opportunities for legitimization, making it the responsibility of the municipality to generate such opportunities while fostering the formation of trade union associations, that is, it had to act as a "legitimizer".

Another alternative that some municipalities (such as Recoleta and Maipú) have begun to adopt for fostering the establishment of associations, especially of workers and microenterprise owners, is the formation of cooperatives. This is often done in collaboration with the Division of Associations and Social Economy (DAES) of the Ministry of the Economy, Development and Tourism.

A special type of public-private coordination occurs between municipalities and international bodies, and between municipalities and universities. While $7 \%$ of municipalities propose policies in the first of these cases, $14 \%$ do in the second. International agreements are conducted with local governments in other countries to coordinate thematic issues in tourism or port cities, among other things. Arrangements with universities are mainly about attracting student internships and performing specific studies on local industry.

\section{Development of the district production system}

In this area, the main proposals have to do with promoting private investment, creating production infrastructure, urban territorial and land use policies, municipal production services and policies on the environment - prepared from an economic and industrial standpoint-, heritage, culture and consumption.

Private investment is an important topic, given that $20 \%$ of municipalities propose policies in this connection. Most of these emphasize the need to design mechanisms to attract investment to the area, which in turn is related both to the dissemination of investment opportunities and to the incentives contained in the district land use plan. With respect to the latter, $12 \%$ of municipalities afford priority to land use for certain types of investment, including technology parks, industrial parks and industrial, agro-industrial and commercial zones - in some cases with infrastructure provided by the municipalityor areas in which the commercial operating licence is cheaper, which means that this parameter is being used as a mechanism of organizing the district's commercial and industrial activity.

The need for municipalities to provide infrastructure for development is evident in their plans in $33 \%$ of cases. These policies relate mainly to tourist infrastructure (such as signage, viewpoints, waterfronts, parks and museums), but also include the provision of production infrastructure for rural sectors (in the form of dikes, dams, irrigation and energy, among others) and commercial activities (markets, fairs and so on). Related to infrastructure is the provision of municipal production services (22\%), which are services supplied directly by the municipality or to its production activities. This category encompasses a very wide range of proposals, from the establishment of a municipal technical training centre (district of El Bosque) to construction of a composting plant (Los Ángeles), municipal city tours (Temuco) and the creation of municipal camping areas (Melipilla), among other initiatives.

The economic development policies set forth in District Development Plans are closely related to the strategic definitions on land use in the District Land Use Plans and include urban territorial policies, a category in which $26 \%$ of municipalities envisage activities. This sort of policy refers to the revitalization of neighbourhoods and central and commercial areas. Another related policy is adding value to heritage (related to the registry and refurbishment of heritage sites), which is undertaken by $16 \%$ of local governments in their economic and industrial plans and is linked in most cases to tourism in the district. 
In relation to heritage, $16 \%$ of municipalities also included policies relating to art and culture, generally linked to tourism and activities that take place in the summer season or at special dates.

Finally, two further topics are associated with district development: environmental policies and consumption policies. While $20 \%$ of municipalities consider the environmental or sustainable development aspect within their industrial and economic policies, only $3 \%$ include policies on consumption. The first revolve around the creation of a recycling industry, the revitalization of parks and green spaces, the inclusion of non-conventional renewable energies in the local production structure (and in the municipality itself), the strengthening of environmental oversight, the dissemination of good sustainable business practices and the fostering of organic agriculture, among others. As for consumption, concern lies above all in the protection of consumer rights through the creation of a Consumers Office in collaboration with the National Consumers Service (SERNAC). ${ }^{11}$

Notably, several of the policies mentioned (especially those on heritage, culture, environment and urban development) are really more numerous than appears here. This is because several district development plans contain specific proposals on urban, environmental, cultural and other ad hoc sections other than those on economic and production development, the area under analysis in this article. Even so, some administrations show an interesting capacity to link up these measures, demonstrating a more comprehensive understanding of the process of local economic development.

\section{Enterprise and business support}

The category of enterprise is present in $72 \%$ of municipalities and, after training, it is the most extensive area of local economic development policy. Enterprise promotion policies consist of business incubators, advice for applying for public and private development funds, the provision of information on government programmes and legal procedures, and training and technical assistance workshops, among others. Direct technical support by municipalities for SMEs, which occurs in $26 \%$ of cases, means having professionals able to support and advise businesses and has been mentioned as a key element both in the category of enterprise and in that of technical support.

Thirteen per cent of municipalities include production diversification polices, involving enterprise support targeting innovative activities in the district and the identification and diffusion of possible new production niches for entrepreneurs in the area.

Another type of policy in this sphere refers to technology and innovation, which is targeted by $29 \%$ of municipalities. This category includes, for example, policies on digital literacy -including training - , the creation of technology parks and technology transfer programmes through agreements with universities.

Four per cent of municipalities propose to strengthen public procurement mechanisms and $26 \%$ propose policies associated with production linkaging. Activities in the former case revolve around training to become a supplier to the public system through the national web portal ChileCompra, and in the latter case they include studies to assess the local industrial situation and foster local SMEs as suppliers to large firms in the district.

Another way in which municipalities have sought to promote local industrial activity has been through policies to disseminate the local supply, a category in which $51 \%$ of municipalities have policies. This sort of policy includes mainly the diffusion of tourism attractions over the Internet, leaflets and advertising plans, and the development of web platforms on local and neighbourhood commerce and

\footnotetext{
11 This type of arrangement is in place in several Chilean municipalities and it involves bringing consumer rights legislation closer to districts with less access to central government institutions.
} 
products. As well as dissemination, $30 \%$ of municipalities propose activities to improve the marketing of local products, which in most cases means setting up permanent websites to showcase and sell these products, especially geared towards craftspeople, small businesspeople and microenterprises, and agricultural products.

There are similar policies promoting the marketing of local products in relation to craft and rural production, which are addressed by $22 \%$ and $25 \%$ of municipalities, respectively. In the case of crafts, policies are aimed largely at marketing through fixed sales points. With respect to rural policies, there is a clear will to increase the coverage of the Local Action Development Programme (PRODESAL), ${ }^{12}$ since the demands are highly varied and relate to specific needs in each particular district.

Another policy category has to do with local seals for products and services, something that $16 \%$ of municipalities include in their plans. This includes plans aimed at increasing the certification of denomination of origin ${ }^{13}$ and certification seals in areas such as forestry and tourism.

In relation to the exhibition and sale of local products are non-permanent markets (such as street markets) and established markets (farmers' markets, producers' markets, flea markets and municipal market stalls, among others), which correspond to policy categories on which $28 \%$ and $31 \%$, respectively, of municipalities have policies. With respect to regular markets, the purpose is to show and offer local products (made by entrepreneurs or craftspeople), sometimes in coordination with craft fairs or other activities organized by the municipality. This type of policy is geared mainly towards non-everyday-consumption products. In the category of permanent markets, the proposals are in the line of establishing municipal markets in districts that lack them; ordering, regulating and revitalizing producers' markets, as well as providing sanitary and cleaning infrastructure, and redirecting itinerant and street commerce into markets, as well as inspecting these, especially in those where food is sold.

The last two categories refer to informal economic activities (32\%) and policy on municipal licences and permits (14\%). The two are related to each other and to policies on permanent markets. In relation to informality, a third of municipalities that refer to this category in their planning afford great importance to the formalization of small enterprise and, especially, itinerant commerce. One of the forms this takes is help for formalizing activities through the establishment of family microenterprises. ${ }^{14}$ In general, the proposals involve drawing up registers of itinerant sellers and encouraging their formalization, as well as offering them training and the option of relocating and, in some cases upgrading their enterprise. They also involve inspection, since the formalization procedures are carried out under municipal by-laws. There are also a number of policies in the category of municipal permits and licences, which are related to the financing of the municipal procedures necessary for micro-entrepreneurs to formalize their activities. Finally, some municipalities seek to improve the procedures for granting permits and licences by preparing or simplifying the respective protocols, setting up one-stop-shops for starting up commercial activities, reviewing and possibly amending the district's commercial by-laws and publicizing the potential benefits of formalization.

\footnotetext{
12 The Local Action Development Programme (PRODESAL) of the Agricultural Development Institute (INDAP) - which reports to the Ministry of Agriculture - is geared towards improving agriculture and livestock production by small producers through technical advice and access to investment funds. PRODESAL is executed by the municipalities or, exceptionally, private entities to which INDAP transfers resources through technical consultancies or investment - under an agreement or contract- complemented by resources contributed by the executing agencies.

${ }^{13}$ Denominations of origin protect the products that originate in a country, region or locality, providing that their quality, reputation or other characteristic can be attributed to the geographical origin. There also have to be other human and natural factors that influence the characterization of the product. Today, any kind of product, not only agricultural, can be protected through recognition of denomination of origin, providing that it meets the requirements set down in the Industrial Property Act, in its ordinances or in other special rules.

${ }^{14}$ The advantage of creating a family microenterprise is the possibility of opting for public grants or loans, and the lifting of bans from operating in commercial or industrial areas included in the respective municipal by-laws, upon due authorization by sanitary authorities or those required by law, as well as access to a simplified business start-up scheme.
} 


\section{District characteristics}

This section moves towards the formulation of an analytical hypothesis aimed at verifying the possible connections between the characteristics of municipalities and the activities that each local government proposes to undertake (expressed in the number of categories of activities included in District Development Plans).

To this end, a sample of 20 districts was taken, drawn from the 69 studied. After sorting the 69 municipalities by the number of categories of their respective District Development Plan, the sample was formed by choosing the 10 municipalities or districts whose plans covered the largest number of categories and the 10 whose plans covered the fewest categories. The aim of this sampling modality was to use the municipalities with the most extreme differences in order to pinpoint more easily the characteristics that are most important in the preparation of the more complex District Development Plans.

The 10 most diversified municipalities, in descending order, were: La Florida (21), Los Andes (21), Iquique (20), Temuco (20), Coquimbo (19), Santiago (19), Villa Alemana (19), Aysén (18), Lebu (18) and Maipú (18). Conversely, the 10 districts with fewest categories in their plans were, in descending order: Arica (5), Estación Central (4), Quilpué (4), Rancagua (4), Renca (4), Castro (3), Quillota (3), San Felipe (3), Ñuñoa (2) and Puente Alto (2).

The method used was a multivariate regression with the number of categories as the dependent variable. The independent variables, classified in three groups, were:

- Relating to the district: if it is a regional or provincial capital or belongs to the Metropolitan Region, total population, ${ }^{15}$ percentage of income poverty and percentage of multidimensional poverty. ${ }^{16}$

- Relating to the municipality: whether the mayor signing the District Development Plan is on the left or right of the political spectrum ${ }^{17}$ and the total municipal budget. ${ }^{18}$

- $\quad$ Relating to the District Development Plan: the year of preparation, its duration, whether it was prepared by an external consultant and whether the process involved public participation. ${ }^{19}$

Given the small number of subjects making up the sample, the results summarized in table 1 should not be treated as definitive proof of relations between the characteristics of municipalities and the actions they plan, but rather as preliminary suggestions for the study of such relations.

The columns in the table represent four difference sets of dependent variables. Although the list of these variables varies, the result remains unchanged: in all cases, the only significant variables are the municipal budget, external consultancy and the fact of being a regional capital.

The positive correlation of the number of categories with the budget is to be expected and it may be interpreted that municipalities with greater resources are more likely to plan activities encompassing a wider range of categories of action.

\footnotetext{
15 In 2016, according to National Statistical Institute data.

${ }^{16}$ Both are data from the 2015 edition of the National Socioeconomic Survey (CASEN).

17 The political right includes Alianza por Chile and the left includes Nueva Mayoría. Independents were classified as left or right by the coalition for which they ran or by their previous party memberships if they ran outside a coalition. The information comes from the Electoral Service of Chile (SERVEL) and the media.

18 In 2016, according to the National Municipal Information System (SINIM).

${ }^{19}$ Public participation was determined using information provided by the Office of the Undersecretary for Regional and Administrative Development (SUBDERE).
} 
Table 1

Chile: characteristics in relation to the number of categories concerning local economic development policies

(Coefficients and standard deviations)

\begin{tabular}{|c|c|c|c|c|}
\hline & (1) & (2) & (3) & (4) \\
\hline \multicolumn{5}{|l|}{ District } \\
\hline Regional capital & $\begin{array}{l}-19.68 \\
(13.03)\end{array}$ & $\begin{array}{r}-17.75^{\star} \\
(8.87)\end{array}$ & $\begin{array}{r}-17.81^{*} \\
(8.25)\end{array}$ & $\begin{array}{r}-17.06^{*} \\
(8.14)\end{array}$ \\
\hline Provincial capital & $\begin{array}{c}2.25 \\
(10.46)\end{array}$ & - & - & - \\
\hline Part of the Metropolitan Region & $\begin{array}{c}-12.67 \\
(9.55)\end{array}$ & $\begin{array}{r}-13.14 \\
(8.71)\end{array}$ & $\begin{array}{c}-13.17 \\
(8.20)\end{array}$ & $\begin{array}{r}-12.78 \\
(8.12)\end{array}$ \\
\hline Total population & $\begin{array}{l}-0.04 \\
(0.03)\end{array}$ & $\begin{array}{c}-0.04 \\
(0.03)\end{array}$ & $\begin{array}{l}-0.04 \\
(0.02)\end{array}$ & $\begin{array}{l}-0.04 \\
(0.02)\end{array}$ \\
\hline Income poverty & $\begin{array}{c}0.01 \\
(0.63)\end{array}$ & $\begin{array}{l}-0.04 \\
(0.03)\end{array}$ & - & - \\
\hline Multidimensional poverty & $\begin{array}{c}0.51 \\
(0.66)\end{array}$ & $\begin{array}{c}0.57 \\
(0.56)\end{array}$ & $\begin{array}{c}0.55 \\
(0.38)\end{array}$ & $\begin{array}{c}0.54 \\
(0.38)\end{array}$ \\
\hline \multicolumn{5}{|l|}{ Municipality } \\
\hline Political orientation & $\begin{array}{l}5.99 \\
(8.18)\end{array}$ & $\begin{array}{c}4.80 \\
(5.69)\end{array}$ & $\begin{array}{c}4.92 \\
(4.68)\end{array}$ & $\begin{array}{l}5.37 \\
(4.61)\end{array}$ \\
\hline Total budget & $\begin{array}{l}0.48^{* *} \\
(0.19)\end{array}$ & $\begin{array}{l}0.47^{\star \star} \\
(0.16)\end{array}$ & $\begin{array}{l}0.47^{\star \star} \\
(0.15)\end{array}$ & $\begin{array}{l}0.46^{\star \star} \\
(0.15)\end{array}$ \\
\hline \multicolumn{5}{|l|}{ District Development Plan } \\
\hline Year & $\begin{array}{l}-1.11 \\
(0.94)\end{array}$ & $\begin{array}{l}-1.10 \\
(0.88)\end{array}$ & $\begin{array}{l}-1.09 \\
(0.83)\end{array}$ & $\begin{array}{l}-1.23 \\
(0.81)\end{array}$ \\
\hline Duration & $\begin{array}{l}-1.98 \\
(2.69)\end{array}$ & $\begin{array}{l}-1.54 \\
(1.65)\end{array}$ & $\begin{array}{l}-1.54 \\
(1.56)\end{array}$ & $\begin{array}{l}-1.47 \\
(1.54)\end{array}$ \\
\hline Consultant & $\begin{array}{c}11.24 \\
(6.57)\end{array}$ & $\begin{array}{c}10.72^{*} \\
(5.74)\end{array}$ & $\begin{array}{c}10.67^{*} \\
(5.28)\end{array}$ & $\begin{array}{l}9.95^{\star} \\
(5.18)\end{array}$ \\
\hline Public participation & $\begin{array}{l}-7.55 \\
(9.07)\end{array}$ & $\begin{array}{l}-7.23 \\
(8.40)\end{array}$ & $\begin{array}{l}-7.25 \\
(7.90)\end{array}$ & - \\
\hline Constant & $\begin{array}{c}2227.06 \\
(1898.41)\end{array}$ & $\begin{array}{c}2205.75 \\
(1779.26)\end{array}$ & $\begin{array}{c}2197.71 \\
(1667.82)\end{array}$ & $\begin{array}{c}2476.07 \\
(1627.06)\end{array}$ \\
\hline $\mathrm{R}^{2}$ squared & 0.05 & 0.16 & 0.25 & 0.27 \\
\hline
\end{tabular}

Source: Prepared by the authors.

Note: ${ }^{*}$ : significant at $10 \%,{ }^{\star \star}$ : significant at $5 \%,{ }^{\star \star *}$ : significant at $1 \%$.

There is also a positive correlation with the use of consultancy firms. In this case, however, the reading is less evident. A positive interpretation would be that the presence of a consultant as a backstop to the municipality's planning capacity enables mayors with that facility to broaden the spectrum of actions in their plans. A less positive reading is the possibility that the more numerous categories reflect the fact that the consultants, having no direct responsibilities in the implementation of the plans they design, propose all the actions that appear theoretically interesting, without applying the stricter filter of what the municipality can do in reality.

The third variable that correlates with the number of categories - in this case negatively - is the fact of being a regional capital. One possible explanation for this is the "displacement" effect of national development institutions. Those institutions concentrate much of their support for development outside Santiago on the regional capitals, which to an extent could lead local governments to leave the issue of local economic development to them and concentrate on other priorities.

Lastly, it is interesting to venture an interpretation of the results with respect to the non-significant variables. First, the intensity of the planning effort does not seem to have any particular political colour, since the adhesion of mayors to different coalitions is not a variable in explaining complexity of District Development Plans in terms of local economic development. The poverty level is not relevant either, which suggests that the motivation to plan actions across more categories is related to a broad range of needs. 
The fact that participation does not explain plan complexity means that plans may be complex either in municipalities that undertake participation strategies or in those that do not, which indicates that those strategies are not an obstacle to preparing more complex plans.

With respect to duration, it might be expected that the longer the planning horizon, the greater the number of categories. The fact that this variable is not significant suggests that there are a large number of municipalities that propose highly diversified activities for short time horizons, which suggests a degree of ingenuity or arbitrariness in the proposals. Lastly, the year of the formulation of the plan could be a sign of a learning process, since, the older the plan, the more likely it is to be out of date and not to have incorporated successive lessons by the formulation of new plans. This was not verified empirically, however.

\section{Conclusions}

The analysis of local economic development policy is a field little explored hitherto in Chile and within economic discipline more broadly. This is probably because of the shortage of information and data for research on the local economic and production structure, and the fundamentally national conception of economic development processes. This research thus aspires to contribute to understanding of the local economic development policies that exist in practice.

A number of reflections and conclusions may be drawn from the analysis of local economic development policies embedded in district development plans. In the first place, it must be noted that the total policies identified in the group of municipalities far exceeds what each one does individually. Of the 40 policy categories identified, the municipalities consulted address on average 16, i.e. $40 \%$ of the existing policy possibilities. At the same time, the existence of these 40 categories reveals the possibility of transcending the welfare-based understanding of local economic development policy, which in practice comes down to lending targeted assistance to the unemployed through workshops, training, labour intermediation and support for microenterprise which, as some District Development Plans indicate, often do not provide lasting solutions to families' economic circumstances.

A second innovative element in the management of local economic development policies has to do with the creation of offices or departments specializing in the subject, which implies moving that responsibility from the existing Community Development Offices (DIDECO) to the recently established Local Economic Development Offices (DIDEL) or unifying the task under Local Economic Development Offices within a department.

A third important aspect concerns the planning horizon, which averages 4.6 years in municipalities. To ensure a clearer alignment with national and regional development plans (which exceed 10 years in length), it would be useful to explore the possibility of establishing 10-year minimum for District Development Plans, in combination with 4-year municipal plans - or government programmescovering the current term in office, always geared towards the strategic planning set forth in the District Development Plan. Long-term planning proposals and greater involvement of local government in the institutional aspects of development are also important when it comes to analysing this new type of approach, since these undoubtedly - as District Development Plans make clear - treat public participation and active coordination with local agents of production as pillars of planning and of related proposals.

Fourth, although many municipalities delegate the preparation of District Development Plans to external consultants, others prepare them themselves. An evaluation of the execution of these plans would require an analysis which clearly exceeds the scope of the present study, but it is important to acknowledge that many municipalities have the basic resources to perform this planning task, which should aim to forge trust between local governments and the public and to obtain the backing and 
legitimacy needed to carry policies to fruition. The place of consultants in plan preparation should be supporting the elaboration of the plan, not so much with respect to the content.

Lastly, municipal characteristics matter as well. Those that appear to be most relevant in explaining more joined-up planning work include the size of the municipal budget, the presence of consultancy firms and the fact of being a regional capital.

Considering the findings of the research, a preliminary response can be made to the initial question underlying the study: the extent to which local economic development policies in Chile are confined to a welfare approach. The evidence set forth indicates that the working modality of local governments is varied. Although the welfare function - a key area of their work - is still present, it is integrated with important actions and decisions concerning the organization of planning work, in which municipalities show great dynamism that set them well apart from the stereotype of passive agencies taking a solely welfarist approach. This is clearly not a consolidated reality or a homogenous phenomenon, but it is evident from the analysis that many municipalities have explored and developed a new way of policymaking, with a more active approach and a more direct assumption of responsibility in promoting local economic development.

Finally, the present study could constitute a useful and interesting analytical tool for local policymakers, who seldom have access to economic studies on the subject. In addition, and in relation to future lines of study, a classification such as the one used here would enable subsequent research including a register of local economic and production development policies actually implemented, which could be prepared on the basis of surveys of agents responsible for local economic development or the review of information contained in the accountability reports of the local administration established under the law (article 67 of the framework law on municipalities). Evaluation of the real impact of each of these policies and initiatives actually carried out is thus another possible avenue of research.

\section{Bibliography}

Alayón, N. R. (1991), Asistencia y asistencialismo: ¿pobres controlados o erradicación de la pobreza?, Rio Piedras, University of Puerto Rico.

Alburquerque, F. (2013), "Economía del desarrollo y desarrollo territorial” [online] http://www.conectadel.org/ wp-content/uploads/downloads/2015/03/E\%C2\%AADesarrollo-y-Desarrollo-Territorial-3.01.pdf. (2004), "El enfoque del desarrollo económico local" [online] http://www.flacsoandes.edu.ec/sites/default/ files/agora/files/1251776298.area_enfoque_del_0.pdf.

Alburquerque, F. and M. Dini (2008), "Módulo 1: empresas, cadenas productivas y territorio. Introducción a los conceptos de innovación, productividad y competitividad" [online] http://www.conectadel.org/ wp-content/uploads/downloads/2013/02/modulo1resumenpdf2011-110623131205-phpapp02.pdf.

Arredondo, J., F. Toro and F. Olea (2007), Política pública y planificación participativa: una mirada desde el ámbito local, Santiago, Ministry of Planning and Cooperation/Regional Secretariat for Planning and Coordination.

Artigas, C. (2005), "Una mirada a la protección social de los derechos humanos y otros contextos internacionales", Social Policy series, No. 110 (LC/L.2354-P), Santiago, Economic Commission for Latin America and the Caribbean (ECLAC).

Becattini, G. (2002), "Del distrito industrial marshalliano a la 'teoría del distrito' contemporánea: una breve reconstrucción crítica", Investigaciones Regionales, No. 1 [online] https://old.aecr.org/images//Imatges Articles/2007/01-Becattini.pdf?_ga=2.249296007.1471150742.1538998641-2111654584.1538998641.

Bianchi, P. and S. Labory (2014), "The role of governance and government in the resilience of regions: the case of the 2012 earthquake in the Emilia-Romagna region in Italy" [online] https://halshs.archives-ouvertes. $\mathrm{fr} / \mathrm{halshs}-01166138$.

Bravo, S. M. (2012), "Implementación de la política de fomento en Chile: una aproximación a partir de la experiencia de las unidades de desarrollo económico a nivel municipal", Santiago, University of Chile [online] http://repositorio.uchile.cl/bitstream/handle/2250/112502/cf-bravo_ss.pdf?sequence=1\&isAllowed=y. 
Camuffo, A. and R. Grandinetti (2005), "I distretti industriali come economie della conoscenza", Argomenti, No. 15 [online] https://www.francoangeli.it/riviste/Scheda_Rivista.aspx?IDArticolo=26026\&Tipo=Artico lo\%20PDF\&idRivista=100.

Garzón, A. and A. Guamán (coords.) (2015), El trabajo garantizado: una propuesta necesaria frente al desempleo y la precarización, Madrid, Akal.

Illanes, M. A. (2010), 'La república de la gratitud: pérdida de democracia y 'chorreo' capitalista en Chile actual”, Ciencias, tecnologías, culturas. El desafío del conocimiento, C. Parker and F. Estenssoro (eds.), Santiago, Explora/University of Santiago.

Montecinos, E. (2006), "Descentralización y democracia en Chile: análisis sobre la participación ciudadana en el presupuesto participativo y el plan de desarrollo comunal”, Revista de Ciencia Política, vol. 26, No. 2, Santiago, Catholic University of Chile.

Olea, F. (2011), Los Planes de Desarrollo Comunal (Pladecos). Región Metropolitana de Santiago, Santiago, Regional Secretariat for Planning and Coordination.

Orellana, A., J. A. Mena and M. Montes (2016), "Plan de desarrollo comunal: ¿el instrumento rector de la gestión municipal en Chile?", Revista INVI, vol. 31, No. 87, Santiago, University of Chile.

Ruz, M. Á. and others (2014), "Planes de desarrollo comunal: propuestas para mejorar su efectividad como instrumento de planificación, participación y rendición de cuentas municipal", Propuestas para Chile, I. Irarrázaval, C. Pozo and M. Letelier (eds.), Santiago, Catholic University of Chile.

Salazar, G. (2013), "Una perspectiva social sobre la historia del municipio en Chile", Revista Iberoamericana de Estudios Municipales, year 4, No. 7, Santiago, Autonomous University of Chile.

United Nations (2016), "Draft outcome document of the United Nations Conference on Housing and Sustainable Urban Development (Habitat III)" (A/CONF.226/4), New York, General Assembly.

Valenzuela, J. P. (2007), Análisis prospectivo de las capacidades institucionales y de gestión de los gobiernos subnacionales en Chile, Washington, D.C., Inter-American Development Bank (IDB).

Ziccardi, A. (coord.) (2004), Participación ciudadana y políticas sociales del ámbito local, Mexico City, National Autonomous University of Mexico. 